\title{
Is jumbo biopsy forceps comparable to cold snare for diminutive colorectal polyps? - a meta-analysis
}

\section{두)(웅}

\section{Authors}

Sachin Srinivasan ${ }^{1}$, Peter D. Siersema ${ }^{2}$, Madhav Desai ${ }^{1}$

Institutions

1 Department of Gastroenterology, Kansas City VA Medical Center, Kansas City, MO

2 Department of Gastroenterology and Hepatology, Radboud University Medical Center, Nijmegen, The Netherlands

submitted 4.5.2020

accepted after revision 29.9.2020

Bibliography

Endoscopy International Open 2021; 09: E9-E13

DOI 10.1055/a-1293-6965

ISSN 2364-3722

(c) 2021. The Author(s).

This is an open access article published by Thieme under the terms of the Creative Commons Attribution-NonDerivative-NonCommercial License, permitting copying and reproduction so long as the original work is given appropriate credit. Contents may not be used for commecial purposes, or adapted, remixed, transformed or built upon. (https://creativecommons.org/licenses/by-nc-nd/4.0/)

Corresponding author

Madhav Desai, MD, MPH, Kansas City VA Medical Center, 4801 Linwood Blvd, Kansas City, MO 64128, United States drmadhavdesai@gmail.com

Supplementary material is available under https://doi.org/10.1055/a-1293-6965

\section{ABSTRACT}

Background and study aims Diminutive colorectal polyps are increasingly being detected and it is not clear whether jumbo biopsy forceps (JBF) has comparable efficacy to that of cold snare polypectomy (CSP) for management of these lesions.

Methods An electronic literature search was performed for studies comparing resection rates of JBF and CSP for diminutive polyps $(\leq 5 \mathrm{~mm})$. The primary outcome was incomplete resection rate (IRR). Secondary outcomes included failure of tissue retrieval and complication rates (postpolypectomy bleeding, perforation etc.). Leave-one-out analysis was performed to examine the disproportionate role of any of the studies. Meta-analysis outcomes and heterogeneity $\left(\mathrm{I}^{2}\right)$ were computed using Comprehensive metaanalysis software.

Results A total of 4 studies ( 3 randomized controlled trials and 1 retrospective study) with 407 patients and 569 total polyps (mean size of $3.62 \mathrm{~mm}$ ) was included for analysis. IRR of JBF was slightly higher than that of CSP $(10.2 \%$ vs $7.2 \%)$ but this was not statistically significantly different (Pooled OR 1.76; 95\% Cl 0.94-3.28; $2^{2}=0$ ). Leave-one-out analysis showed no significant difference in the pooled $O R$ comparison either. Two of the 4 studies reported $0 \%$ failure of tissue retrieval for JBF and $1 \%$ and $4.3 \%$ for CSP. There were no complications for either group from the 2 studies that reported this outcome. The quality of the included studies was moderate to high.

Conclusions This systematic review with only limited data shows that JBF and CSP are not statistically different in completely removing diminutive polyps, although careful endoscopic assessment is needed to ensure complete removal of all polyp tissue.

\section{Introduction}

Colorectal cancer (CRC) is the $2^{\text {nd }}$ leading cause of cancer in both men and women in the United States [1]. Screening colonoscopy helps to identify precancerous colorectal polyps and their prompt removal could prevent malignant transformation. According to the current guidelines, endoscopic polyp size measurement is key in determining surveillance intervals. Small
$(<10 \mathrm{~mm})$ and diminutive $(\leq 5 \mathrm{~mm})$ colorectal polyps are the most common type of colorectal polyps found during colonoscopy especially when using higher resolution endoscopes, distal attachment devices and improvements in bowel preparation [2].

While it is known that the neoplastic potential of these small and diminutive polyps is low, studies have shown that incomplete (or inadequate) polyp resection could contribute to post 
colonoscopy colon cancer in up to $30 \%$ of patients [1]. Incomplete resection rates (IRR) of $10 \%$ to $15 \%$ have been reported for standard capacity biopsy forceps, cold snare (CSP) and hot snare across polyps of all sizes [3]. Studies have demonstrated that the resection rates of these diminutive polyps by hot biopsy forceps are suboptimal compared to cold techniques [4]. However, there is some degree of variation in the resection rate among cold polypectomy techniques itself. CSP appears to be safer as well as more effective than standard capacity forceps in the management of small and diminutive polyps [4].

Jumbo biopsy forceps (JBF), a type of cold forceps which in comparison to standard capacity forceps and large capacity forceps, can accommodate more polyp tissue $\left(12.44 \mathrm{~mm}^{3}\right.$ vs $7.22 \mathrm{~mm}^{3}$ ) and offer removal of diminutive polyps in entirety. A meta-analysis from 2016 [5] suggested that cold snare or jumbo biopsy decreased the rates of incomplete resection by $60 \%$ without any increase in procedure time. However, none of the studies included in this analysis were from a head-to-head comparison.

Recently, some studies [6-8] have been published examining JBF to CSP for efficacy in diminutive polyp resection. However, variable rates have been reported, and it remains unclear which method is better. Since diminutive polyps are a common occurrence in screening and surveillance colonoscopy, knowledge of effective polypectomy techniques is crucial. We performed a systematic review and meta-analysis of the literature to examine the efficacy and safety of JBF and CSP in the management of diminutive polyps.

\section{Methods}

We performed this systematic review and meta-analysis in accordance with the PRISMA guidelines [9]. The search strategy for screening, excluding and final selection of studies is depicted in Fig. 1.

\section{Literature search}

We searched online electronic libraries (PubMed, EMBASE, Web of Science, Google Scholar) until February $1^{\text {st }}, 2020$ for studies comparing JBF and CSP and resection of diminutive colorectal polyps. The following keywords "jumbo biopsy forceps", "cold snare polypectomy"," small polyps" and "diminutive polyps".

\section{Eligibility}

We primarily included articles that reported dimunitive polyp resection data using jumbo biopsy forceps AND cold snare (inclusion criteria). Case reports, case series, cross sectional studies and review articles were excluded for this review and analysis.

\section{Screening and data collection}

Articles were screened and data was extracted by one reviewer (SS) and verified independently by another reviewer (MD). Duplicate studies were excluded, and titles/abstracts were screened for study of interest. Only articles that met eligibility were included for final review and analysis

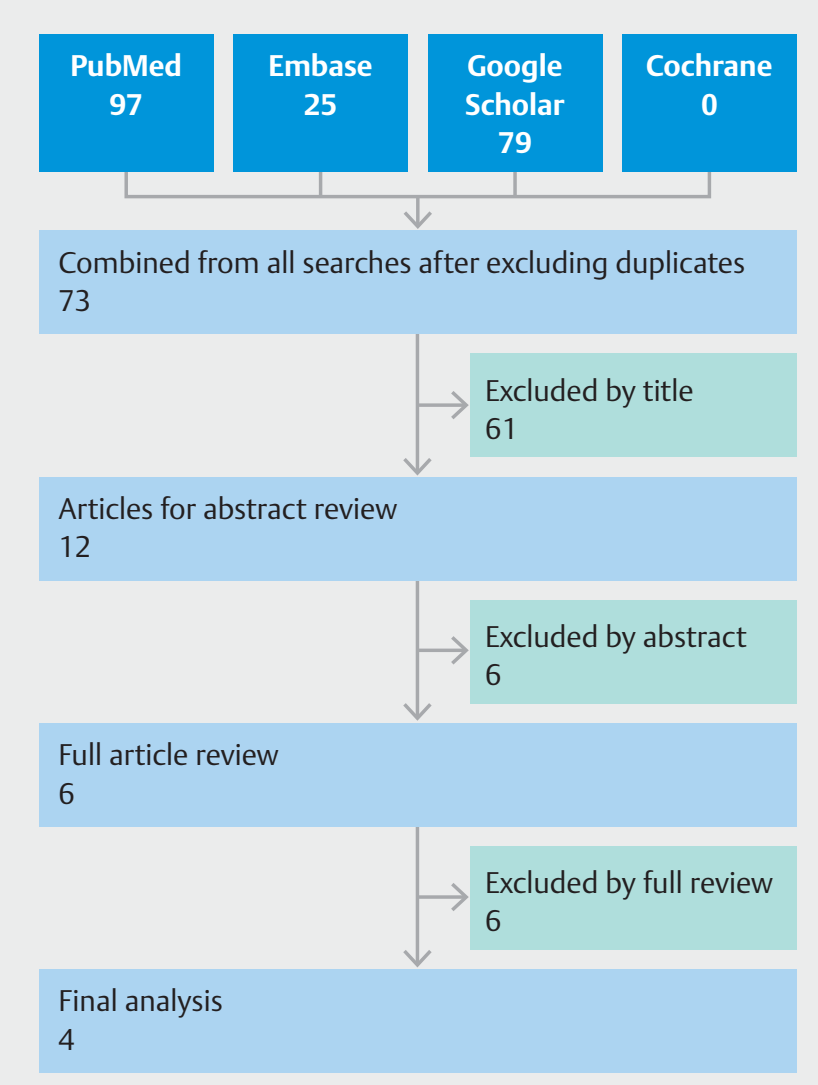

Fig. 1 Search schematic for review and inclusion of articles.

\section{Quality assessment of studies}

Cochrane risk of bias tool [10] was used to assess the quality of RCTs while Newcastle Ottawa scale (NOS) [11] was used to examine study quality of the retrospective cohort study. Scoring was done per protocol across all the respective domains.

\section{Definitions}

Incomplete resection rate-reflects the number of polyps incompletely resected (i. e. with residual neoplastic tissue left behind) divided by the total number of polyps resected

Failure of tissue retrieval rate - rate at which the polyp/tissue attempted to be resected and retrieved was not successful

Complications - any untoward event that occurred as a direct result of the endoscopic procedure and/or related instrumentation.

\section{Outcomes}

The primary outcome of interest was the pooled IRR of JBF and CSP when treating diminutive polyps. Secondary outcomes included failure of tissue retrieval, long-term follow up outcomes and complications rates following use of either modality (postpolypectomy bleeding, perforation etc.)

\section{Statistical analysis}

Pooled estimates using proportions from each group were compared using a fixed-effects model with odds ratio (OR) and 
Table 1 Descriptive characteristics of included studies.

\begin{tabular}{|c|c|c|c|c|c|c|c|c|c|}
\hline Author & $\begin{array}{l}\text { Year of } \\
\text { publi- } \\
\text { cation }\end{array}$ & Type of study & $\begin{array}{l}\text { Total } \\
\text { no. of } \\
\text { subjects }\end{array}$ & $\begin{array}{l}\text { Total } \\
\text { no. of } \\
\text { polyps }\end{array}$ & $\begin{array}{l}\text { Avg } \\
\text { polyp } \\
\text { size (in } \\
\mathrm{mm} \text { ) }\end{array}$ & Males & $\begin{array}{l}\text { Mean } \\
\text { age (in } \\
\text { years) }\end{array}$ & $\begin{array}{l}\text { Incomplete } \\
\text { resection by } \\
\text { JBF/Total no. } \\
\text { resected by JBF }\end{array}$ & $\begin{array}{l}\text { Incomplete } \\
\text { resection by } \\
\text { CSP/Total no. } \\
\text { resected by CSP }\end{array}$ \\
\hline $\begin{array}{l}\text { Gonzalez } \\
{[8]}\end{array}$ & 2010 & $\mathrm{RCT}$ & 40 & 66 & 3.3 & $\begin{array}{l}\text { Not re- } \\
\text { ported }\end{array}$ & $\begin{array}{l}\text { Not re- } \\
\text { ported }\end{array}$ & $4 / 33$ & $1 / 33$ \\
\hline Liu [12] & 2012 & $\begin{array}{l}\text { Retrospective } \\
\text { cohort study }\end{array}$ & 47 & 65 & 4.5 & $\begin{array}{l}\text { Not re- } \\
\text { ported }\end{array}$ & $\begin{array}{l}\text { Not re- } \\
\text { ported }\end{array}$ & $2 / 18$ & $1 / 7$ \\
\hline Huh [7] & 2019 & $\begin{array}{l}\text { RCT; Non-infer- } \\
\text { iority trial }\end{array}$ & 169 & 177 & 3.9 & 131 & 61.9 & $7 / 87$ & $7 / 90$ \\
\hline Desai [6] & 2019 & $\mathrm{RCT}$ & 151 & 261 & 3.3 & 104 & 63.1 & $16 / 144$ & $9 / 117$ \\
\hline
\end{tabular}

$95 \% \mathrm{Cl}$. Leave-one-out analysis was performed to examine a disproportionate role of any single study. $l^{2}$ statistics was computed to assess for heterogeneity. Meta analytic calculations and forest plots were created by statistical software Comprehensive Meta-analysis v3 (Biostat, Englewood, New Jersey, United States]. $P<0.05$ was considered statistically significant.

\section{Results}

\section{Characteristics of included studies}

The initial search yielded 201 articles. After removal of duplicates, there were 73 articles that were eligible for review. Of these, 61 were removed after review of the title, six of the abstract and two articles were excluded after full review, respectively, since they did not meet inclusion criteria. Finally, four articles were included for review and meta-analysis.

Of the four included articles, three were RCTs [6-8], with one study as abstract only data [7] and one was a retrospective cohort study ( $\triangleright$ Table 1) [12]. One of the studies [7] had a noninferiority study design while the others seemed to have followed convenience sampling. Another study that was included [8] was abstract only (interim data from 2010) and there was no record of a full publication.

There were 407 patients with 569 total polyps (mean size $3.62 \mathrm{~mm}$ ) reported from the included studies. Of these patients, $81 \%$ (from 3 studies) were males with a mean age of $62.5 \pm 0.8$ years (from 2 studies).

Data on IRR was available from all four studies. Only two of the four studies reported data on failure of tissue retrieval and post-polypectomy complications. None of the studies had long-term follow data for review.

\section{Primary outcome}

IRR of JBF seemed to be slightly higher than CSP (10.2\% vs $7.2 \%)$ but this was not statistically significantly different (Pooled OR 1.76; 95\% Cl 0.94-3.28) ( Fig.2). There was no heterogeneity $\left(I^{2}=0\right)$ among the studies included for analysis. One of the studies, Desai et al [6] contributed to nearly half of the overall analysis while the Gonzalez et al paper [8] had an OR of 4.4 comparing JBF versus CSP that was significantly different from the other studies.

We also performed a leave-one-out analysis to ensure that the results were not skewed because of a single study ( $\triangleright$ Fig. 3). There was no statistically significant difference in IRR noted with this analysis either.

\section{Secondary outcome}

Two of the four studies reported $0 \%$ failure of tissue retrieval for JBF and $1 \%$ and $4.3 \%$ for CSP ([7] and [6] respectively). None of the studies provided any long-term follow-up or rates of interval cancer following resection. The same studies reported complication (post-polypectomy bleeding, perforation) rates which were $0 \%$ in both groups.

\section{Quality assessment of the studies}

All of the RCTs included were at low risk of bias for randomization, incomplete data or selective data reporting. None of the studies were blinded. The retrospective study was high (score 7 ) on the Newcastle Ottawa scale ( $\triangleright$ Table 2). Publication bias was not examined due to only four eligible studies.

\section{Discussion}

In this meta-analysis of four available studies, there was no statistically significant difference noted in the incomplete resection rates of JBF and CSP when removing diminutive polyps. Because only three small RCTs were involved, it is too early to conclude whether either of method fares better to remove diminutive polyps or that they indeed can both be used. It is imperative to note that with either method there is a substantial incomplete resection rate $(7 \%-10 \%)$ and careful examination of the post polypectomy site is essential even when a diminutive polyp is removed.

With the improving detection modalities (higher resolution endoscopes, artificial intelligence etc.) detection of smaller polyps is and will be increasingly seen. While it is known that the overall risk of malignant transformation of small and diminutive polyps is low $(<1 \%)$ [13], it nevertheless puts a burden on the health care system (procedure/resection cost and pa- 


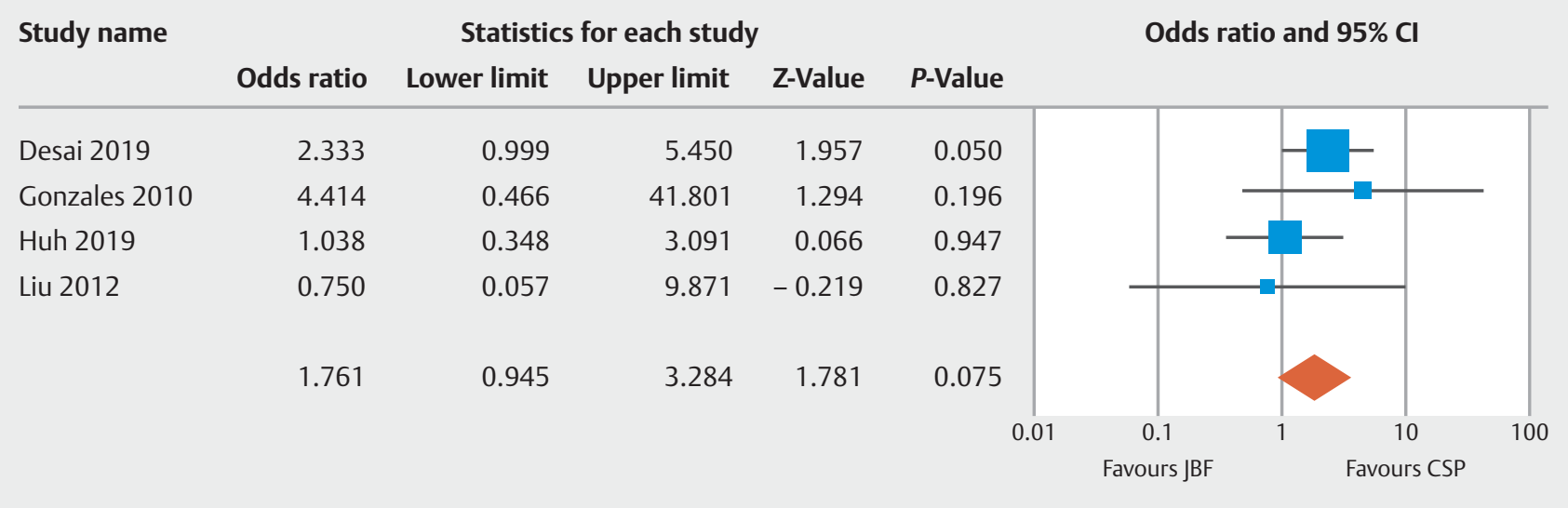

- Fig. 2 Forest plot comparing incomplete resection rates of JBF and CSP.

\section{Study name}

Desai 2019

Gonzales 2010

Huh 2019

Liu 2012
Statistics with study removed

Point Lower limit Upper limit Z-Value

1.267

1.632

0.506

2.274

1.857

1.761

0.853
1.065
0.977

0.977

0.945

$\begin{array}{ll}3.173 & 0.506 \\ 3.120 & 1.480 \\ 4.856 & 2.123 \\ 3.529 & 1.890\end{array}$

\section{P-Value}

0.613
0.139
0.034
0.059

3.284

1.781

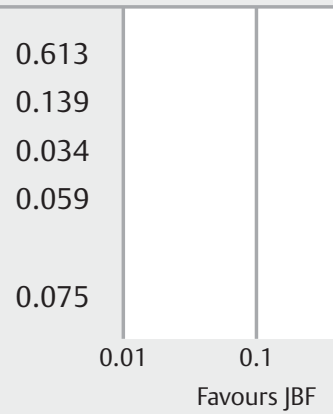

Odds ratio $(95 \% \mathrm{Cl})$ with study removed

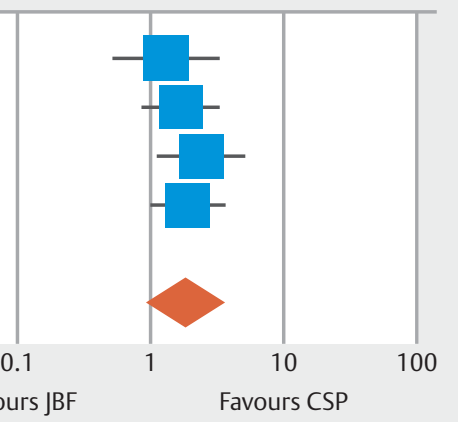

- Fig. 3 Leave-one-out forest plot of the included studies.

\begin{tabular}{|c|c|c|c|c|c|c|c|c|}
\hline $\begin{array}{l}\text { Cochrane } \\
\text { risk of bias } \\
\text { for RCT }\end{array}$ & $\begin{array}{l}\text { Random } \\
\text { sequence } \\
\text { generation }\end{array}$ & $\begin{array}{l}\text { Allocation } \\
\text { conceal- } \\
\text { ment }\end{array}$ & $\begin{array}{l}\text { Blinding } \\
\text { of partici- } \\
\text { pants }\end{array}$ & $\begin{array}{l}\text { Deviation from } \\
\text { intended out- } \\
\text { come }\end{array}$ & $\begin{array}{l}\text { Incomplete } \\
\text { outcome data }\end{array}$ & $\begin{array}{l}\text { Selec- } \\
\text { tive re- } \\
\text { porting }\end{array}$ & Other bias & \\
\hline $\begin{array}{l}\text { Gonzalez } \\
2010\end{array}$ & Unclear & Unclear & No & Unclear & Unclear & Low & Unclear & \\
\hline Huh 2019 & Low & Low & High & Low & Low & Low & Low & \\
\hline Desai 2019 & Low & Unclear & High & Low & Low & Low & Low & \\
\hline $\begin{array}{l}\text { Newcastle } \\
\text { Ottawa } \\
\text { scale for } \\
\text { observa- } \\
\text { tional } \\
\text { study }\end{array}$ & $\begin{array}{l}\text { Representa- } \\
\text { tiveness } \\
\text { of the exposed } \\
\text { cohort }\end{array}$ & $\begin{array}{l}\text { Selection } \\
\text { of the } \\
\text { non-ex- } \\
\text { posed co- } \\
\text { hort }\end{array}$ & $\begin{array}{l}\text { Ascertain- } \\
\text { ment of } \\
\text { exposure }\end{array}$ & $\begin{array}{l}\text { Demonstration } \\
\text { that outcome of } \\
\text { interest was not } \\
\text { present at start } \\
\text { of study }\end{array}$ & $\begin{array}{l}\text { Comparability } \\
\text { of cohorts on } \\
\text { the basis of the } \\
\text { design or anal- } \\
\text { ysis }\end{array}$ & $\begin{array}{l}\text { Assess- } \\
\text { ment of } \\
\text { outcome }\end{array}$ & $\begin{array}{l}\text { Was fol- } \\
\text { low up } \\
\text { long e- } \\
\text { nough for } \\
\text { outcomes } \\
\text { to occur }\end{array}$ & $\begin{array}{l}\text { Ade- } \\
\text { quacy of } \\
\text { follow } \\
\text { up of } \\
\text { cohorts }\end{array}$ \\
\hline Liu 2012 & * & * & $*$ & - & $*$ & $*$ & * & $*$ \\
\hline
\end{tabular}

thology expenses) in addition to the risk of complications from the procedure itself.
The safety and efficacy of CSP have been established and it is currently the most preferred modality of resection of diminutive polyps [5]. Hot forceps even though currently approved 
have shown significantly higher IRR (up to $53 \%$ ) [14] making them less effective. Cold forceps fair better in comparison [14] but the literature is sparse comparing them to JBF. The wider jaw $(8.8 \mathrm{~mm})$ of the JBF with a better bite makes it likely to grasp more tissue and thus have a lesser IRR compared to the standard biopsy forceps [15]. This way resection margins of removed tissue could be examined better for clean resection margin to ensure adequacy of resection as well. This meta-analysis supports the comparable nature of JBF and CSP in addressing these polyps.

It is worthy of mention that one of the studies [7] intended to evaluate non-inferiority of JBF over CSP but the other studies did not have any such hypothesis. It is unclear, but unlikely that this has any impact on pooled results since results were generated using events of outcome and total subjects. However, this could play a role towards the final results as a power required to detect a non-difference could be very different from a power required to detect a difference. In leave-one-out analysis, we were not able to detect this effect, but this could still be possible.

A large number of polyps ( $n=569)$, low heterogeneity $\left(I^{2}=0\right)$ and the quality of studies included are the strength of these studies. Some of the limitations pertain to that of any meta-analysis, i.e. that it reports pooled data only and might be subject to skewing owing to some of the included studies. Another limitation is the total number of included studies $(n=4)$. Of these, one of the studies [8] was abstract only data and it is possible that the full text had some additional information that could change the reported results. Of the four studies that met eligibility, three were RCTs and were of reasonably high quality. While we did include a cohort study thus raising a concern for potential confounding bias, restricting the analysis to RCT alone did not change the results. We were not able to conduct further analysis of certain factors (viz. residual and recurrence rates, change in surveillance intervals and time required for effective polypectomy) because of lack of information from the included studies. There was also no information on whether polyps were removed en-bloc or use of any special techniques (lift and cut, etc.). The studies lacked information on longterm follow-up data making the above-mentioned calculations not possible. Future studies should focus on accuracy of resection methods from either technique and rate of (long-term) residual and recurrent polyp to further define their efficacy.

\section{Conclusion}

In conclusion, based on the findings, jumbo biopsy forceps seem not statistically different to cold snare polypectomy in the management of diminutive polyps. Further head to head large scale trials are necessary to find any small difference that would have been masked by prior studies with focus on diminutive polyps to avoid incomplete resection and improve quality of colonoscopy.
Competing interests

The authors declare that they have no conflict of interest.

\section{References}

[1] Leung K, Pinsky P, Laiyemo O et al. Ongoing colorectal cancer risk despite surveillance colonoscopy:the polyp prevention trial continued follow-up study. Gastrointest Endosc 2010; 71: 111-117

[2] Lee CK, Shim J-J, Jang JY. Cold snare polypectomy vs. Cold forceps polypectomy using double-biopsy technique for removal of diminutive colorectal polyps: a prospective randomized study. Am J Gastroenterol 2013; 108: 1593-1600

[3] Pohl H, Srivastava A, Bensen SP et al. Incomplete polyp resection during colonoscopy-results of thecomplete adenoma resection (CARE) study. Gastroenterology 2013; 144: 74-80.e1

[4] Tranquillini CV, Bernardo WM, Brunaldi VO et al. Best polypectomy technique for small and diminutive colorectal polyps: A systematic review and meta-analysis. Arq Gastroenterol 2018; 55: 358-368

[5] Raad D, Tripathi P, Cooper G et al. Role of the cold biopsy technique in diminutive and small colonic polyp removal: a systematic review and meta-analysis. Gastrointest Endosc 2016; 83: 508-515

[6] Desai S, Gupta S, Copur-Dahi N et al. A prospective randomized study comparing jumbo biopsy forceps to cold snare for the resection of diminutive colorectal polyps. Surg Endosc 2020; 34: 1206-1213

[7] Huh CW, Kim JS, Choi HH et al. Jumbo biopsy forceps versus cold snares for removing diminutive colorectal polyps: a prospective randomized controlled trial. Gastrointest Endosc 2019; 90: 105-111

[8] Gonzalez I, Riley DE, Ho SB et al. M1523: Quality Colonoscopy: midterm results of a qualitative comparison of cold snare versus cold biopsy forceps for the resection of colonic polyps. Gastrointest Endosc 2010; 71: AB244

[9] Moher D, Liberati A, Tetzlaff J et al. Preferred Reporting Items for Systematic Reviews and Meta-Analyses: The PRISMA Statement. PLOS Med 2009; 6: e1000097

[10] Higgins JPT, Altman DG, Gøtzsche PC et al. The Cochrane Collaboration's tool for assessing risk of bias in randomised trials. BMJ 2011; 343: d5928

[11] Wells G, Shea B, O'Connell D. The Newcastle-Ottawa Scale (NOS) for assessing the quality of nonrandomised studies in meta-analyses. Sci Open; 2015: Available at: https://www.scienceopen.com/document? vid=54b48470-4655-4081-b5d4-e8ebe8d1792e

[12] Liu S, Ho SB, Krinsky ML. Quality of polyp resection during colonoscopy: are we achieving polyp clearance? Dig Dis Sci 2012; 57: 17861791

[13] Ponugoti PL, Cummings OW, Rex DK. Risk of cancer in small and diminutive colorectal polyps. Dig Liver Dis 2017; 49: 34-37

[14] Komeda Y, Kashida H, Sakurai T et al. Removal of diminutive colorectal polyps: A prospective randomized clinical trial between cold snare polypectomy and hot forceps biopsy. World J Gastroenterol 2017; 23: 328-335

[15] Draganov PV, Chang MN, Alkhasawneh A et al. Randomized, controlled trial of standard, large-capacity versus jumbo biopsy forceps for polypectomy of small, sessile, colorectal polyps. Gastrointest Endosc 2012; 75: 118-126 